\title{
「商業近代化運動」の論理／倫理
}

——商業コンサルタントによる「安売り」をめぐる言説に着目して—

\section{林 凌*}

1960 年代日本に抢いては, チェーンストアの急拡大という小売業界の構造 変化が生じた．この時期ダイエーや西友などの小売企業は, 全国各地に相次い で店舗を立地した？その結果「安売り」を基盤とした大量販売体制が日本にお いても生起したのである.

流通史研究はこうした小売業界の構造変化において, 商業コンサルタントと でも呼びうる職能集団が重大な役割を有していたことを指摘している。だがな ぜ彼らは，それまで否定されていた様々な経営施策を肯定的な形で取り上げた のか. この点について, 既往研究は充分な説明を加えているとは言い難い.

本稿では消費社会研究の知見を分析の手がかりとして, 当時「商業近代化運 動」に取り組んでいた商業コンサルタントの「安売り」をめぐる言説に着目し, 以下のことを解明する．第 1 に, 商業コンサルタントが「商業近代化運動」に おいて「安売り」を肯定的に取り上げた際に，「安売り」と「乱売」が「大量 生産一大量消費」の杂組みから弁別されていたということを説明する. 第 2 に, こうした「安売り」という施策の重要性を訴える主張が, 当時の経営学の導入 と密接に結びついていたということを説明する。 そして第 3 に, こうした「安 売り」をめぐる彼らの実践が「消費社会」の到来という予期を原動力にしてお り，そのため「消費者」への貢献という規範が，「安売り」という具体的施策 と結びっく形で当時強く示されていたことを明らかにする.

キーワード：消費, 小売業, 大量販売

\section{1 はじめに}

\section{1 問題の所在}

本稿の目的は,「安売り」という販売施策の重要性を訴える商業コンサルタント の言説実践を通じて,「商業近代化運動」の思想的背景とその意味を考察すること にある. 具体的には, 当時彼らが「消費社会」到来の予期を原動力としてこの運動 に取り組んで抢り, そのため「安売り」に基づいたチェーンストアの展開を「大量

* 東京大学大学院学際情報学府博士課程 assyupokira@gmail.com 
生産一大量消費」を媒介する「大量販売」を実現するための方策として訴え, 小売 商の商業倫理の書き換えを図っていたことを明らかにする。こうした分析を通じて， 本稿では今まで論じられてこなかった商業コンサルタントの言説実践における「消 費社会」概念の重要性を浮き彫りにするとともに, 小売業者がこぞってチェーンス トア化に打って出た 1960 年代において生じた，小売業をめぐる認識の転換を示す こととしたい.

「チェーンストアで安売りされた商品を購入する」，この一文に当てはまるような 行為をしたことがない人間は，おそらく現代日本社会において存在しないだろう. こう言い切ってしまっていいほどに, チェーンストアという存在はありふれており, またそこで販売される商品にセールの值札がついていることも珍しいことではない. 事実, こうした店舗群や店舗の施策そのものに対し, 消費社会の変容を見出そうと する言説が複数成立するほど, チェーンストアは私たちの日常生活と強く結びつい ている（若林編 2013; 近森・工藤編 2013).

だが, こうして対象化される「チェーンストアが遍在する社会」は，少なくとも 日本においては 1960 年代後半以降に成立したものである. 戦後日本の小売業界に おいては, 一部の百貨店を除けば資本・労働力・ノウハウのいずれにも乏しい零細 小売商1)がその大半を占めており（石原 2004：280-1），そこには今みられるような 近代的経営体としての小売企業はほとんど存在していなかった.

ではいかにしてチェーンストアは日本に現れたのか.この新たな小売業の可能性 を見出したのは, 小売業者でも消費者でもなく, 商業コンサルタントという知識人 集団であった，彼らは 1960 年代初頭, 「商業近代化運動」と呼ばれる活動を通じて, 様々なノウハウを小売業者に教導するとともに, チェーンストアという業態の可能 性を伝えていった（矢作 1997：34-57）。これが結果的に小売業界の構造変化の引 き金を引いたのである.

しかし, そもそもなぜ彼らはこの時期小売業の革新を訴え, その中でチェーンス トアという業態に強く肩入れしたのか. またどのようにして彼らは改革の機運が低 い零細小売商を対象に, 自らの正当性を訴えたのか. この点について, 既往研究は 小売業界の構造変化における「商業近代化運動」が果たした役割を当然視するあま り, 十分に記述を行っていない.つまり,「商業近代化運動」が彼らによってこの 時期強烈に推進され, なおかつチェーンストアという業態が彼らの活動の中で有力 視された理由の説明がなされていないのである.このことは, チェーンストア業態 がいかにして成立したのかを検討する流通史研究の観点からも，あるいは「チェー ンストアが遍在する社会」とはいかなる社会かを検討する消費社会研究の観点から も，問題であると考えられるだろう.

\section{2 分析の視角一一商業近代化運動」の思想的背景への着目}

この問題を検討するにあたって, 本稿は当時の同時代的な社会変容と, それをめ ぐる人々の認識の変化に照準を合わせる. 特に商業コンサルタントの言説実践を, 
単なる「商業近代化運動」の証拠として捉えるだけではなく，本運動を論拠立てて 説明し, 正当化しょうとする実践としても捉えることで, 彼らの活動の思想的背景 を解明する．具体的には，1960 年代における「大量生産一大量消費」を前提とし た「消費社会」化の進行という認識が, 商業コンサルタントを「商業近代化運動」 に向かわせる原動力となっていたということを，以下では述べたい.

なぜこのようなパースペクティブを採用するのか. 第 1 に, 同時代的な時代情勢 との連関のもとで, 本運動の生起理由を説明することができるからである. 当時先 験的に小売業革新の重要性を訴えた林周二（1962）の主張が, 非現実的だとして多 くの批判を浴び, 型破りであると捉えられていたこと到は, 当時の小売業革新の機 運が必ずしも十分なものではなかったことを示している。では彼らはこのような状 況下において，どのようにして小売業革新の重要性を訴えたのか. この点を解明す るためには, 当時の彼らの言説において，「商業近代化」がなぜ成されなければな らないのかを説明する言表を分析しなければならない3）.

第 2 に, 同時代的な「消費社会」をめぐる認識を記述する言説に着目することで, 消費社会研究が積み上げてきた知見を再検討することになるからである. 消費社会 研究においては, 「大量生産一大量消費」を司る産業技術の定着に伴い, 量的かつ 質的な社会の変容が生じるということが, さまざまな形で述べられてきた（内田 1987: 30-51 など). だが一方で，こうした消費社会研究の観察の図式そのものは， 観察対象と独立して存在していたわけではない. 新倉貴仁（2015：143-4, 2016: 172-81）が示しているように，戦後日本においては「大量生産一大量消費」という 枠組みは幅広く共有され, 産業技術の進歩を背景としたさまざまな議論が知識人層 を中心に行われていた。つまり, 消費社会研究が述べてきた「消費社会」の成立過 程には, ある種再帰的な「消費社会」にまつわる認識と, それに基づいた人々の実 践が存在していたのである.

このことを踏まえるのならば，同時代的な「消費社会」をめぐる人々の認識が, いかなる形で「消費社会」化と呼ばれる社会の変容に影響を与えていたのかという 問いが, 消費社会研究における新たな課題として浮上してくる.「消費社会」を支 えるさまざまな技術・ノウハウは, どのような言説の布置のもと導入されようとし ていたのか. このことが，「消費社会」の進行と変容を考える上で，あらためて分 析されなければならない. その意味において本稿は. 単に流通史研究で分析されて きた「商業近代化運動」の原動力を推し量るだけでなく，「大量生産一大量消費」 という消費社会研究が重視してきた分析枠組みそれ自体が, 1960 年代日本におけ る小売業界の構造変化に, 大きな影響を与えていたことを明らかにするものでもあ る.

\section{2 分析する資料の特質と本稿の構成}

この観点より商業コンサルタントの言説を分析するにあたって, 本稿では特に 
「安売り」という一一定価以下の価格で商品を恒常的に販売する一一販売施策をめ ぐる言説に着目する. これは, 当時の日本における小売業の構造変容と, それに伴 う社会変容を考察するにあたって，本施策と関連する言説が重要であると考えられ るからである，以下では，その理由について論述を行う。

第 1 に「安売り」という施策が, 重要な経営資源としてその後チェーンストアを 運営する小売業者に認識されるようになったにもかかわらず, 1960 年代初頭にお いては極めてネガティブな施策としてみられていたということが指摘できる. 戦後 すぐの日本においては, 商品を安く売るという行為は夕ブー視される傾向にあり,

「安売り」を行おうとした事業者に対し妨害や嫌がらせが行われることも珍しいこ とではなかった（崔 2004：110）。つまり「安売り」という施策の普及は, 日本に おける小売業界の構造変化において, もっとも困難な問題の 1 つであったのであり, それゆえその唱導過程においては「商業近代化運動」を遂行するにあたっての, 商 業コンサルタントの問題意識がよく表出されると考えられる.

第 2 に, 「安売り」という施策の登場は, 当時の「消費社会」をめぐる社会変容 の認識と直結していると考えられるからである，詳しくは後述するが，商業コンサ ルタントはこの時期さまざまな言説実践を通じて, 自らが述べる「安売り」が, そ れまでの「乱売」とは異なり, 正当な施策であると強調している. こうした言表の 存在は, 商品を安く売るという施策が強くタブー視されていたことを示すものでも あるが，重要なのは彼らが「安売り」の正当性を，「大量生産一大量消費」という 枠組みと, それを構成する諸技術に求めていたという点である。この点を踏まえる のならば,「安売り」をめぐる商業コンサルタントの言説を分析することは, 彼ら が「消費社会」化という社会変容が生じているという認識のもと, 「商業近代化運 動」に取り組んでいたことを示すことになるといえるだろう.

そしてこの「商業近代化運動」に携わる商業コンサルタントらの言説実践を, 最 も多く掲載していた媒体が雑誌『商業界』4)である，株式会社「商業界」の発行す る本誌には, 1960 年代初頭にかけて多くの「安売り」に関する文章が掲載されて いた. また同社は雑誌刊行のみならず, 店舗運営ノウハウや財務管理の手法を伝授 する「ゼミナール」の宣伝や，小売業に関する英米圈の翻訳資料やコンサルタント が執筆する書籍の販売も行うことで, 日本小売業界に最先端の知識を伝達する役割 も有していた、いわば『商業界』は,「商業近代化運動」における中心的な広報誌 としての機能を有していたのである ${ }^{5)}$.ゆえに本稿では, 「商業近代化運動」の黎 明期である 1960 年代初頭, 『商業界』に揭載された商業コンサルタントらによるテ クストを資料体として設定する。

最後に本稿の構成を述べる，第 1 に，商業コンサルタントが「商業近代化運動」 において「安売り」を肯定的に取り上げた際に,「安売り」と「乱売」が,「大量生 産一大量消費」に適合的かという観点から弁別されていたということを説明する.

第 2 に, この「安売り」という施策の重要性を訴える主張が, 当時の経営学的知識 の導入と密接に結びついていたということを説明する。 そして第 3 に, こうした 
「安売り」をめぐる彼らの実践が「消費社会」の到来という予期を原動力にしてお り,「消費者」への貢献という新しい商業倫理が,「安売り」という具体的施策と結 びつく形で当時強く示されていたことを明らかにする. 以上の構成を通じて, 本稿 では「商業近代化運動」を司っていた商業コンサルタントの実践が, 当時の社会変 容にまつわる認識と色濃く結びついていたということを示すこととしたい.

\section{3 商業コンサルタントによる「安売り」の再定義}

以上の問題設定より, 本稿では「商業近代化運動」の思想的背景を検討する. 特 に以下では，それまで夕ブーであった「安売り」という施策を「商業近代化」に必 須のものとして正当化していく，商業コンサルタントの言説を分析することとなる.

だがその前に，私たちは当時の「安売り」をめぐるイメージがどのようなものだ ったのかについて, 今一度みておく必要があるだろう。当時の「安売り」という施 策に関するイメージについては, ボランタリーチェーン研究所の所長を務めていた 萬田一治により書かれた，以下の小売商向けの文章によく表れている.

安売り屋について述べるといえば, その問題ならば, 先刻承知で, 過去に随 分悩まされ，どうやら収まったところであるから，寝ている子供を抢こすよう なことは止めて呉れ，という人もいようと思う。(『商業界』1962.2: 43)

「安売り」を紹介することは，1950 年代初頭における乱売競争 ${ }^{6)}$ (倉本 1960：47) を思い起こさせる，「寝ている子供を抗こすようなこと」であり，「止めて呉れ」と 思う人も「いよう」と考元られうるものであった。「安売り」は多くの小売商にと って忌避される施策であったということは，彼の文章からも認めることができる. だが一方で, 彼はこう続けるのである.

これから述べょうと思っているディスカウント・ハウスの実相は, 恐らく皆 さんの想像もしていないようなものであろう。つまり安売り屋は安売り屋でも, 過去の安売り屋にない, 新しい要素が加わっている. この要素を究めることに よって, はじめて近代的小売店経営の実相が捉えられようといえようし, また 自分の店の今後に益するところが多かろうと思う。(『商業界』1962.2: 43)

ここで彼は自分が紹介する「ディスカウント・ハウス」を，「安売り屋は安売り 屋でも, 過去の安売り屋にない, 新しい要素が加わっている」とすることで, 「安 売り」という施策を正当なものとして紹介しょうとしている.つまり彼は「安売 り」という概念を再定義することによって正当化しようとしているのである. 


\section{1 「安売り」を「乱売」と弁別する一一大量生産一大量消費」枠組みの導入}

では，その再定義を支える「実相」とは何か. それを理解するためには，当時の 小売業者が抱いていた「安売り」に対する忌避感が, なぜ醸成されたのかを検討す る必要性がある。「安売り」はなぜ問題含みだったのか. 当時新潟大学教授であり, 株式会社ジャスコ（現イオン）の取締役にもその後就任した, 商学者の川崎進一は 以下のように指摘する.

指示価格又は指定価格, 或いは定価というものがある……その小売価格は, 必ずしも守られていない…...小売業者のなかには，直接的積極的に価格を引き 下げようと努力している人がいる，称して安売屋といわれ，或いは乱売屋とも いわれている. 何が, 安売りであり, 何が乱売であるかあまり明確でないうち に，これらの業者は同業者に非難され，ヒンシュクをかっていたのである。そ して，この安売りによって，圧迫される同業者は，道義的に正価を問題とし， 或いは，道徳的に乱売を問題とする。（『商業界』1961.1：105）

メーカーが指定する定価は，小売業者が必ずしも守る必要がないものである。一 般に卸值が定価より安くなる以上，利幅を削りさえすれば定価以下の価格で商品を 販売する「安売り」は可能だからだ。しかしそうした行為は, 他店からの顧客の収 奪に繫がりうるため, 多くの場合「何が，安売りであり，何が乱売であるかあまり 明確でないうちに」,「同業者に非難され，ヒンシュクをかっていた」.「安売り」は, 定価を「道徳」とすることでそれを非難し, 価格決定権を卸売, あるいはメーカー に依拠しようとする小売業者の活動によって，困難なものとなっていたのである.

しかし，なぜ定価は道義的に守らなければいけないものとされ，なおかつそれに 多くの小売業者が従っていたのだろうか. 雑誌『商業界』の主幹であり, 戦前・戦 後問わず日本商業コンサルタント界の中心にいた倉本長治の意見を見てみよう。

物や，サービスを売るのが商人なのだが，一つの商品に值段をつけるに際し ても……何事も他の仲間のやる通り……る商店が有利な方法と思ったり， 正 しいと信じたりして，商品の自主性のある独特のネダンを広告すると，これを 〔組合が〕禁圧する……かかも人一人に対してそれぞれ異なる「人の顔色を 見て行なう不公正, 不公平な」商売をしていながら, 公然と誰に対しても公平 なネダンで販売をする場合だけを抑えようとしてることが多いのである。（『商 業界』1961.2: 60-1)

先述したとおり当時の小売商の資本基盤は極めて脆弱であり, 独自の経営施策を 打つことは困難であった。 よって商店街組合や業種組合などに依存した横並び型の 販売施策を, 彼らはとらざるをえず, 場合によってはメーカーによる価格カルテル の要請も断れる状況ではなかった（『商業界』1961.1：109）。親族などに便宜を図 
ることが許容されたとしても，万人に「安売り」を行抢うとする業者は多くの場合， 同業者や組合などから強い妨害にあい，それに抗うことも難しかったのである （『商業界』1961.1：36-7)．小売業者の経営革新は，多くの場合同業者や，市場価 格の下落を嫌うメーカーによって排除される傾向にあった。「安売り」をタブー視 する態度は，こうした組合組織が強い影響力を有していた当時の小売業の状況と， それによって生じる価格をめぐる軘轢によって生じており, ゆえにこの問題の解決 は，非常に難しいものとなっていたのだ.

そしてこうした状況から，萬田が「安売り」を「過去」と「新しい」という用語 法によって区分した理由がみえてくる，すなわち，「過去」の「安売り」とはこう したさまざまな問題を内包したものであったのである。「安売り」という言葉には 忌避感がこびりついて抢り，ゆえに彼はわざわざ「新しい」という弁明をしなけれ ばならなかった。

ではなにが「新しい」のか．それはこの「安売り」がアメリカに抏いて成立して いる,「大量販売」を実現する販売形態なのであるという点に求められた。つまり ここで示されている小売業の後進性とは, アメリカと比較してのそれであり，「近 代化」という言葉はアメリカの小売業にならうことを示すために用いられている.

ディスカウント・ハウスは, 経費を省きコストを切り下げ, 取引量の増大で 消費者価格を引き下げて行く, 最近の米国販売業界の新しい動向の一つに過ぎ ない……值引きが経営のバックボーンになっているということは……私は敢え て商業界の革命であるといいたい。（『商業界』1962.2：44-5)

「ディスカウント・ハウス」と「安売り屋・乱売屋」の差異は, このようにして アメリカにおける先進的な経営手法, すなわち大量生産商品の大量販売による価格 の引き下げに求められる（渥美 1967：115-20）。それは零細小売商の所属する組合 が保持する規範からの逸脱を意味する「乱売」とは，販売システム面においてまっ たく異なるものであるとみなされたのだ，川崎が言うように，彼らにとって「安く 売ること、乱売とは，まるでちがったこと」(『商業界』1961.1：106）であり，だ からこそ「商業界の革命」である「安売り」は拒絶されるべきものではないとされ た.「大量生産一大量消費」を媒介する「大量販売」に資するものとして「安売り」 を取り上げたがゆえに，彼らはこの施策を「商業近代化運動」の中核に据えたので ある。

\section{2 「安売り」の意義を指し示す一一計数管理と経営目的の提起}

「安売り」が小売業に扔けるタブーではなく，積極的に推進されるべき施策であ るとするならば，いかにしてそれを実現するのかが問題となる。つまり，「大量販 売」を実現する「近代的小売経営」の一環として，「安売り」を行うためにはアメ リカの例にならう必要性がある以上，それまでの日本における小売業のあり方は変 
革されなければならない.

ではどのようにして彼らは変革をもたらそうとしたのか. ここで鍵となるのが, 「商業近代化運動」においてその重要性が主張されていた計数管理という概念であ る. 小売業の零細性と低生産性を可視化し問題を洗いだすための手段として, 経営 学的手法を用いた分析がこの時期大幅に進むようになる.

計数管理とは，読んで字のとおり，計数を基礎として経営をコントロールす ることで, 在来のカシや経営による経営に合理性, 近代性を与えようとするも のです……ううでもなく, 計数管理は経営目的達成のための手段ないしは方 法であって，それ自体が必ずしも価值あるものではありません……したがって， 正しい計数管理の前提には正しい経営目的の確立がなくてはなりません.（『商 業界』1960.6: 33)

1960 年代前半の『商業界』において, 計数管理を紹介する記事は頻繁に掲載さ れており, 商業コンサルタントがこの手法の伝導に注力していたことは明らかであ $ろ^{7)}$. この計数管理という概念は, 当時販売計画の策定や損益分岐点, ROI (Return On Investment）の同定といった会計学的手法や（『商業界』1960.6: 30-51), パンチ・カードを用いた顧客セグメントの同定（『商業界』1960.7: 105-11), 店員 の作業分析（『商業界』1960.9: 134-8）といった, さまざまな経営に関する分析手 法を包括した言葉として用いられていた。つまりそれは,「暗黒大陸」(Drucker $1962=1962$ : 114）とも呼ばれていた流通業の不透明な販売システムを可視化し, それまで勘や経験のみで行われていた小売業の経営の中にどのような問題があるの かを明らかにしようとする試みであったといえるだろう。

ここで重要なのは, こうした分析手法を効率的に活用するためには目指すべき未 来, すなわち経営目的が必要となると, 彼らが考えていたということである. あく までも計数管理が現況を正確に把握するためのツールにすぎない以上，それをどの ように改善するのかという方向性は, 小売業者それぞれの志向に委ねられている. ゆえに，小売業界における経営革新は経営目的の確立と計数管理の徹底によって, 初めて可能になるものとみなされた.

このような論理のもと,「安売り」は「消費者」概念と強く結びつくことによっ て，計数管理に基ついた経営目的を達成する施策の一つとして提起される。つまり， 「社会大衆の福祉をできうるかぎり増進」(『商業界』1960.6: 33) するという目的 を達成する一つのやり方として, 「安売り」が提起されるようになるのである. 商 業コンサルタントによる「商業近代化運動」において,「安売り」と計数管理は —その後の経営学的な言説の中でしばしばみられるような——単なる因果関係に あるというよりも「小売商の社会的使命」（『商業界』1961.4: 108）を達成するた めの機能的要件として位置づけられていた。 それは以下の川崎の言明を見れば明ら かである. 
価格は固定的なものではなく, 最後に, 消費者が判定するものである…… 間には, 乱売屋とみられながら, 実は, 安く仕入れて, 店の自主的採算価格で 廉販する店がある。これは，けっして乱売屋ではない…...消費者に良心的な安 いものを提供するのが商店の責任だからである. 安いということが, 販売経営 の合理化，能率化によるものであるならば，文句はない筈である。（『商業界』 1961.4: 107-8)

ゆえに彼らが計数管理を商業近代化に必須のものであるとみなしたことを，単に 経営学的思考を小売企業の活動の中に埋込もうとしたためと捉えるべきではない. それは小売業に扔けるそれまでのさまざまな慣習を打ち破り, 彼らが望む新しい小 売業を確立するにあたって, 自らの正当性を主張するために必要な概念だったので あり，そのためアメリカの先進的な経営学者の言説が，正当化の資源として用いら れたのである. 計数管理による合理的な運営のもと, 確固たる経営目的を推し進め る小売企業の誕生を彼らは望んでいた，そしてその経営目的として主に考えられて いたのが,「安売り」を行うことによって「消費者」一般の利益を増大させることな のであった。 つまり, 経済合理性に基づく企業経営が小売業においても一般となる べきであると主張されたことによって，「安売り」はそれまでの「乱売」とは異な る「小売商の社会的使命」を果たすための施策として，正当化されたのである.

しかしながら,こうした一連の議論をたどった後も, 私たちのもとにはまだ解決 されていない問題が残っている. すなわち, なぜ彼らは「商業近代化運動」を推進 するにあたって, ことさらに「商業界の革命」や「小売商の社会的使命」といった 記述を行わなければならなかったのだろうか.「チェーンストアが遍在する社会」 に生きる私たちにとって, こうした精神論的記述が「安売り」施策導入のために繰 り返されていたことは，一見不可解である.

次節では，この点について理解を深めるとともに，「商業近代化運動」が単なる 経営手法の導入ではなく, 特定の倫理観を小売業者に唱導しょうとする運動でもあ ったということを明らかにすることで, 彼らの「安売り」を推進する言説が「消費 社会」の到来という予期によって強く推進されていたということを明らかにしたい.

\section{4 「消費社会」の到来という予期——商業近代化運動」の論理 $/$ 倫理}

私たちは繰り返し, 当時の小売業をめぐる環境が, 商業コンサルタントによって 問題視されていたということを参照してきた.メーカーや卸売商に対して劣位な資 本と, 同業者が加入する組合のルールに制約された小売商の活動は, 彼らにとって 満足行くものではなかったのである.

だがなぜ彼らはこうした小売業の状況に満足いかなかったのか. それは, 彼らが 近い将来日本においても「大量生産一大量消費」を基軸とした「消費社会」が到来 すると予期していたからである. 現況の小売業界をボトムアップ的に改善すること 
ではなく, 多少強引であったとしても「消費社会」成立の期日に向け,「大量生産 一大量消費」体制に対応することができる小売業を日本社会の中に定位させること が, 彼らの運動の主眼なのであった.

ゆえにこの運動は, 今まで議論してきたような計数管理や販売施策などの, いわ ばノウハウの伝導だけにとどまるものではなかった，彼らは自らが抱く「消費社 会」像に必要な「大量販売」を推進することを通じて,「商業近代化」が歴史的必 然性を有している小売企業の使命なのだと繰り返し主張した。つまりこの運動は, 高度経済成長下に扔いても新たな経営施策を取り入れようとしない小売商の，「卑 屈な商人根性を根こそぎ吒き直」(『商業界』1961. 臨時増刊：7）し，商業にまつ わる倫理を書き換えようとする運動でもあったのだそそしてこの倫理観の転換を目 指す言説実践に扔いて最も象徴的であったのが，本稿が取り扱った「安売り」をめ ぐる議論なのである.

商人が最低の売価で良品を販売するということが正義であり, 永遠の使命で あることを痛感しなくてはなるまい，廉売店で栄えた試しがないなどというの は, 大嘘である……令や海の向うの小売業界を眺めると, 滔々として低マージ ン, 低価セール, 低利潤の波涛いよいよ激しく, 経営の緻密な計算に基づく極 めて微妙な利益管理の行われているのを見る. オートメーションーマスプロー マスコミが招来したマスセールの必然が齊した当然の現象なのである……廉売 こそ量産商品に関す方限方, 現段階の経済界の至上命令なのである。（『商業 界』1960.4: 74)

この倉本の記述をみるとき, 私たちは商業コンサルタントが当時有していた将来 像を理解することができる，彼らにとって日本の商業は，今までみてきたようにア メリカに比して, 後進的なものとみなされていた，だが一方でそれは，同じ日本と いう国家に掠いて，大量生産を実現している工業に比しても後進的であると考えら れていたのである。「生産態勢は著しく改善され，その能率は上昇した，独り商業 だけが, 『終戦直後』の状態をつづけている，改善されないままに眠りにふけって いる」(『商業界』1961.1: 109) という認識が, 彼らの「商業近代化運動」のべー スにあった，そしてそれは，小売業界の体質に起因するものであると考えられてい た。

であるから，彼らにとって小売業を近代化するとは，先進的な小売業のノウハウ を単に諸外国から導入するということを意味しない，そもそもそうしたノウハウを 受け入れる土壤が, 当時の小売業にはないと考えられていたからである（倉本 1960：46-8).「商業近代化」とは, たしかに先進的なアメリカにおける小売業のノ ウハウを日本にも適用可能な形で展開することを意味しているものの, その導入を 可能とする認識そのもの——消費社会」の到来という認識——小売商に教導し ようとする試みでもあった。つまり日本においても始まりつつある「マスセール」 
の流れに追随する形で, 「最低の売価で良品を販売するという」ことこそが小売業 の「永遠の使命」であることを，小売商に伝えることが, まず彼らにとって契緊の 課題だったのである.

こうした認識をもつ彼らにとって, 既存の小売商のあり方は打破されなければい けない対象としてみなされた。ゆえに株式会社「商業界」が主催するセミナーにお いて, 倉本に代表される商業コンサルタントは, 繰り返し販売施策などの手法だけ ではなく, 商人がもつべき態度——真商道」(『商業界』1961.4 臨時増刊 : 2)— を主張するようになる。

これまでも, 企業の経営とか, 販売の技術かを論じ, 事業の繁栄を説くもの が多かったし，わが国にも商店経営指導家と称ばれる特殊職業人も数あったが ……倫理についてはあまり顧みられることがなく, それは飽迄も,「如何にし てヨリ多くの利潤を稼ぎ出すか」を目途として，それから一歩も外へは出なか ったのだ. その点, 私の考えは根本から違っていた……商売も儲けなければ やって行けないが, 断じて儲けるのがその目的ではない」とするのである. 商 人も公共社会をお互いに構成する人間である以上，人としての「善い」「正し い」在り方を求願して営業す可しという立場をとる。（『商業界』1961.4 臨時 増刊 : 4-5)

ここで倉本は, それまでの「商店経営指導家と称ばれる特殊職業人」と自らの違 いを，商業に関する新たな「倫理」を語るかどうかに見出している．つまり，「如 何にしてヨリ多くの利潤を稼ぎ出すか」のみに固執し，日本における小売業の立ち 位置や「消費者」に対する利益還元を省みようとしない既存の小売商のありさま, すなわち旧来の商業に関わる倫理を, 彼は「商業近代化」を阻むものとして問題視 したのだ。そのため彼は精神論的にも聞こえる「商人も公共社会をお互いに構成す る人間である以上，人としての『善い』『正しい』在り方を求願して営業す可しと いう立場」が, 新しい小売商がもつべき倫理なのだと主張する. そしてこの倫理観 の延長線上に, 商業コンサルタントはさまざまな「商業近代化」の方策を, 不可避 的な「消費社会」に順応する方法として紹介したのである.

ここで重要なのは，「消費社会」の到来という予期が，こうした彼らの言説実践 の基底をなしていたということである. 今までみてきたとおり, 彼らにとって日本 の小売商は改革されるべき対象であるとみなされていた。 それは小売商の販売施策 が, 仲間内の都合を優先する旧来の倫理に凝り固まっており, なおかつ近代的経営 学に基づいた計数管理的手法を十分に摂取していないからである。だがこうした小 売商の「後進的」態度が問題となるのは, それでは来るべき「消費社会」において 実現される「大量生産一大量消費」を媒介する，「大量販売」体制を形成すること ができないと彼らが考えていたからにほかならない。言い換えるのならば，「消費 社会」の到来という予期のリアリティが非常に強かったからこそ, 彼らは単にノウ 
ハウとしての「商業近代化」に飽き足らず，小売企業がもつべき倫理的態度をも 「商業近代化運動」において強く述べる必要性に迫られたのであった（『商業界』 1961.4 臨時増刊：18).

そしてこうした倫理が具体的なノウハウとともに商業コンサルタントによって主 張されたことは, 小売企業がさまざまなくびきから逃れ, 自らの企業活動を正当化 する資源を手に入れることを意味した，というのも，同業者の同調圧力やメーカー による価格カルテルの強制は, 「消費者利益」という規範のもとでは己の利益のみ を保持しようとする，唾棄すべき活動になるからである．「消費者」という社会集 団の利益が主張され, 小売商全体の利益に対置されるとき,「消費者」の利益を守 ろうとするあらゆる企業活動は, たとえそれまで忌避されていた施策であったとし ても許容されるようになる。「消費社会」の到来という予期は，小売業者が自らの それまでにない企業活動を肯定的な形で説明できるようになる素地を作り出したが, それは「消費者」という社会集団への奉仕という倫理観が,「大量販売」を導く新 しい販売施策と非常に親和的だったことを意味している.

事実, 商業コンサルタントによるこの時期の言説実践には,「大量販売」体制の 実現と,「消費者」への貢献を直結して捉える議論が目立つ.「ヨリ多くの利潤を稼 ぎ出すか」ではなく,「消費者利益をいかにして増やすか」という正しい倫理に基 づく行動であるがゆえに, 大量販売体制につながりうるさまざまな小売企業の活動 は一一をえ結果的に「ヨリ多くの利潤を稼ぎ出す」活動であっても一一正当化さ れるのである。

私は店の大きいことや，売上の多いことが良いとは決して思ってはいない． だが, 小さな店でも, その経営が正しく, 消費大衆に喜びや愉しみや, 便宜や 利益を惜しみなく与え続ける時, その店は断じて, いつまでも小さなままでは 居ない, そうしておりたくも, 世の中が許さないのだと説いているのである ……商売は大きいから良いのではなく, 正しく行なわれ, 消費者の幸福を懸命 に守っているか否かが良い悪いのケジメとなるものなのである。（『商業界』 1962.8: 35-8)

こうした倉本の態度からは, 当然の事ながらそれまでの小売業にみられた性質が 顧みられることはない。店舗の大小や売上の多寡ではなく，「消費大衆に喜びや愉 しみや, 便宜や利益を惜しみなく与え続ける」かどうかで小売企業の活動の「正 し」さが判断されるとき, 逆説的ではあるが, それまでの零細小売業のあり方はお おむね否定される。というのも, 彼らが語る「消費者」への奉仕は, とどのつまり 「商業近代化」を通じた「消費社会」への対応を目指す動きである以上, 必然的に 計数管理に則ったチェーンストア化や店舗の大規模化を促すものとなるからだ (『商業界』1960.7：38). 1960 年代, 商業コンサルタントは「消費社会」の到来を 予期したがゆえに,「商業近代化運動」を通じてそれまでの小売商の活動を否定し, 
「大量生産一大量消費」を媒介する「大量販売」体制を作り上げようとしていた そしてその過程の中で, かつてタブーであった「安売り」という販売施策は, 「消 費者」に奉仕し，「消費社会」実現の一助となる施策として捉えられたがゆえに， 正当化されたのである.

\section{5 おわりに——同時代言説としての「消費社会」論}

本稿では，それまでタブーであった「安売り」を販売施策として肯定的に取り上 げた商業コンサルタントの言説実践を通じて,「商業近代化運動」の思想的背景と その意味を考察してきた。戦後日本において，小売業界は革新の気運が薄く，特に 「安売り」はメーカーや卸売商，小売商との軋軪を生む施策としてタブー視されて いた．こうした状況において「消費社会」の到来を予期し，日本の小売業が「大量 生産一大量消費」を媒介するに不十分であることを問題視した商業コンサルタント は,「商業近代化運動」と呼ばれる活動を通じて, 小売業界の変革を企図していた. 彼らはアメリカに打ける「近代的」な小売業態・ノウハウを伝導するとともに, 「消費社会」の到来が不可避的であると論じることによって, 小売業界全体の革新 を迫った。大量生産一大量消費」が目の前に迫っている以上，小売業界は「大量 販売」を可能とする仕組みを作らねばならず，そのためには過去の因習や考え方を 捨て,「消費者」への貢献を経営目的としなければならないと, 彼らは考えたので ある．このような認識を支えていたのは，同時代的なアメリカの「消費社会」のあ り様と, 日本の製造業のオートメーション化に伴う技術革新であり，この 2 つの対 象の観察が，彼らを「商業近代化運動」に向かわせていた，そしてこうした背景の もと,「安売り」は過去の「乱売」と異なり確固たる計数管理に基づいており，「消 費者」の幸福を増大させるがゆえに，「小売商の社会的使命」を果たすものである と主張されたのである.

ではこの「商業近代化運動」を通じた「安売り」をめぐる言説実践は, どのよう な社会的意味を有していたとみることができるだろうか．それはその後の小売業者 が「安売り」を軸として自らの活動を語れるようになったということに, 最もよく あらわれているといえるだろう.ダイエーの中内功が「良い品をどんどん安く売る これがダイエー憲法のすべてである……゙イイー憲法がめざすところは，消費者の ための企業である」（中内 1969：4-6） と述べたように，1960 年代後半以降さまさ まな小売業者が自らの活動の意義を，「安売り」による「消費者」への貢献にある と説明するようになった，彼らは自らの活動を後ろめたいものではなく，正しいも のとして語れるようになったのである.このような語りのスタイルは, 1960 年代 以前にはほぼ見ることができない(8). なぜならば，「安売り」を正当な施策として 捉えるためには, 今まで本稿が論じてきたように近代的経営学に基づいた計数管理 という論理と,「消費社会」の主役たる「消費者」への貢献という倫理が導入され る必要があるからである.つまりこの「安売り」をめぐる商業コンサルタントの言 
説実践は，チェーンストアという業態をノウハウとして導入するだけでなく，それ を運営する企業の活動に対する抄墨付きを，「消費者」という概念を提起すること によって与えたのである.

そしてさらに重要なのは，こうした「消費者」への貢献という倫理は，その後の 小売業界における重要な原理原則として受容されていったということである. 1970 年代以降, チェーンストアが日本全国を覆い尽くし，大量販売体制が一区切りとは いえ成立した後,「安売り」という施策に依拠した企業経営に対し, 小売業者や消 費者団体から反対意見が出るようになる. しかし彼らは「安売り」を批判する論拠 を, それがあくまでも「消費者」, あるいは現代の変容する「消費社会」に適合し ていないという点に求めたのであった（奥住 1983: 294-7)。こうした態度は, 同 じ「安売り」に対する批判であったとしても, 倉本長治が批判したような短期的利 益のみを追い求める 1950 年代までの一般的な小売商のあり様とは決定的に異なっ ている。っまり，「安売り」に賛同するにせよ反対するにせよ，「安売り」を唱導す るために持ち込まれた倫理そのものは, 小売業界一般に, あるいは日本社会全般に 広く膾多されたのである。その意味において,「商業近代化運動」は単に「安売り」 に基づいたチェーンストアという業態を広めるという役割のみならず，「消費者」 という社会集団を措定するという語りの枠組みを小売業界全体に定着させたという 点に，その歴史的役割を見出すことができるだろう．

最後に今後の展望を述べる，本稿では「安売り」をめぐる商業コンサルタントの 言説を通じて, 当時の小売業の構造変化を先導した「商業近代化運動」が「消費社 会」の予期を原動力として進行していたこと, そしてそれがその後の小売業界に打 ける実践の礎となる論理／倫理を提供してきたことを記述してきた。彼らの実践は， 単にアメリカの先進的な経営学を取り入れるという次元にとどまらず,「大量生産 一大量消費」を基軸とした「消費社会」の到来を予期し, 小売業界全体を特定の将 来像に適合した形へ改変しょうとした点に，その社会学的な分析意義を見出すこと ができる．というのも彼らは消費社会研究が分析してきたような社会変容に関わっ ていただけでなく，消費社会研究が分析の枠組みとして用いていた構図そのものも 並行して摂取し，自らの実践に活かしていたからである。この点を踏まえるのなら ば，「消費社会」の成立過程を検討する上で，「消費社会」を語る言説が同時代的に 与えた影響，すなわち「消費社会」の自己成就性を，あらためて検討しなければな らないことがわかる.

特に本稿においては商業コンサルタントの言説に分析の的を絞ったものの,「消 費社会」を語る言説の同時代的影響をこの観点より検討するのならば，小売業者や 卸売業者といった商業に関わる別のアクター, さらには製造業者, 消費者団体など が生み出す言説についても分析の対象とし, どのようにして彼らが「消費社会」に まつわる言説を受容し，再帰的に自らの役割を規定していったのかがあらためて問 われなければならないだろう。その意味において, 消費社会研究が用いてきた分析 枠組みは, いかなる形で当事者によって社会を記述するためのツールとして用いら 
れてきたのかが，歴史的資料を通じて検証されなければならない段階にきているの である。

\section{[注]}

1）本稿において「小売商」と「小売企業」は異なる概念として取り扱う。具体的には「小売 商」は「商業近代化」以前の，あるいは「商業近代化」を受け入れょうとしない小売業者のこ とであり，「小売企業」とは「商業近代化」の動きを積極的に取り入れようとした小売業者の ことを指す。こうした弁別を行うのは, 事実として商業近代化を受け入れることなしに小売業 の組織的経営を行うことが困難であった以上,「企業」という言葉は限定的に用いたほうが適 切だからである.

2）林（1962）の『流通革命—製品・経路扔よび消費者』は，当時ベストセラーとして多くの 論争を巻き起こした．ここではそのすべてを紹介するわけにはいかないが，その反論について は扔打むね以下の 3 つにまとめることができる. 第 1 に, 雑誌『販売革新』において明治大教 授の三上富三郎が掲載した論文にみられるように，その主張（=流通チャネルの近代化）には お打むね賛成するものの, その具体的手法に対する反駁（=流通チャネルに対する積極的な政 策関与への反対）を述べたものである（『販売革新』1963.8: 17-21). 第 2 に, 一橋大教授の坂 本二郎（1963: 250-8）の言説にみられるように, 日本という特殊社会においては林が述べてい るようなアメリカ型の消費社会は根付きえないとするものである. 第 3 に, 日専連の宗像平八 郎（1963：266-74）が述べているように，林の議論は統計資料との乘離が大きく実証的裏付け のない極論とするものである．これらの反論は，総じて林の主張がアメリカ流の消費社会の到 来を所与のものとしており，論理記述に難があることを問題としている，だが，本稿で述べる ように，林のこの書籍はある種の予言書として小売業者に受け取られたきらいがある，そのた め林の言説の社会的意味は，言説の精緻さとはまた異なるレベルで分析される必要があるよう に思われる.

3）このような分析視角をとる方法論的意義は以下の通りである. 第 1 に, こうした観点から資 料を分析することによって, しばしば流通史研究が用いるイノベーションの源泉としてのみ彼 らの実践に着目する視角（矢作 1997：252-5）から逃れることができるからである.より正確 にいうのならば, 本稿では彼らの実践を単なる「商業近代化」の一要件として捉えるのではな く, そうした「商業近代化」という言葉で括られる施策体系が, そもそもどのような唱導過程 のもと私たちの社会の中に埋め込まれたのかを理解しょうとしている. 第 2 に, このような記 述法を通じて私たちは，「消費社会」という概念が現代社会の中でリアリティをもって使用さ れるようになる過程の一端を理解できるようになる。つまり本稿で試みられるのは,「消費社 会」という概念が小売業の変革を導くための資源として動員されていき，具体的な施策や物的 対象と結びっくことに伴って,「他でもなく〔そうで〕あるように語られていくその機序を浮 かび上がらせる」(加島 2014: 26) ことなのである.

4）株式会社「商業界」は, 商業コンサルタントである倉本長治, 新保民八らによって設立され ているが, もともと彼らは誠文堂新光社によって 1922 年より発行され, 戦中の休刊を挟んで 1946 年に復刊した雑誌『商店界』に寄稿していた，彼らが『商店界』を離れ「商業界」を設立 した理由は明らかではないが, 『商業界』が他の専門誌と大きく違ったのは, ゼミナールと彼 らが呼ぶセミナーを通じて, 紙面上に留まらない相互的な交流を重視していたことである。特 に倉本が重視した「体験発表」と呼ばれる, 小売企業の成功事例を具体的な数字も併せ, 会員 全体で共有するセミナーの運営手法は，参加会員の活動に大きな影響を与えた。 その意味にお 
いて『商業界』は, 経営学に基づいた運営がほとんど成されていなかった当時の小売業界に, 大きな影響を与えていたと考えることができる.

5）もちろん, 株式会社「商業界」のみが当時の小売業界において「商業近代化」の主導的役割 を担っていたわけではない，日本初のスーパーマーケットコンサルタントである喜多村実が運 営していた「公開経営指導協会」や，当時小売業に関する書籍の翻訳を積極的に手がけていた 「日本専門店連合会」, レジスター会社である日本 NCR が自社商品の拡販を図るために設立し た「フレンド・ナショナル」など, 当時複数のネットワークが「商業近代化」を推進していた (長戸 1991：40-6; 渥美 2007：38-41)．ただこうした組織に所属する人々も，『商業界』への寄 稿を多く行っており, 複数存在する「商業近代化運動」のハブとして機能していたのが『商業 界』だったのだと考えることはできるだろう．

6）戦後日本小売業界に拈ける「安売り」のタブー化については, 抒掠むね以下のような形で整 理できる。まず, 戦後すぐは流通チャネル全体の未熟さゆえに, 商品の安定供給が不可能であ り, 商品の過剩供給などがしばしばなされた（奥住 1983: 31-3).この過剩在庫は, 最終的に 立場の弱い小売商へとなだれ込む傾向にあった，そしてこの過剩在庫を安く買い付け廉価に販 売することで,「乱売合戦」を引き起こす事業者が出現する（林 1961：91-111）。だが自己資本 にそしい零細小売商にとって, 過剩在庫を長期抱え込むことは倒産を意味するため, 彼らはさ まざまな手段を用いて「乱売」を行う事業者を強く排除するようになる。こうした流れの中で, 「安売り」は小売商の生活を脅かすものとしてタブー視されていくようになるのである.

7）たとえば, 雑誌『商業界』の 1960 年の 6 月号では「計数管理のすべて」と題して, 計数管 理のノウハウやその意味についての論考が多くの商業コンサルタントによって特集されている (『商業界』1960.6: 30-51). またその後も計数管理についての記事は数多くみられる（『商業 界』1962.4: 69-74など).

8）もちろん，後世から見た評価にそうした記述が紛れ込むことはよくある．たとえばチェーン ストアの拡大に強い影響力を有していた商業コンサルタントである渥美俊一は, 自らの活動が 江戸時代の商家のそれと同一のポリシーを有していたということを主張している（渥美 2007: 2-3).だがここで重要なのは, こうした記述が事後的な語り直しによってのみ担保されている という点である.つまり, 彼らは今までの自らの活動の意義を説明し正当化する必要に迫られ たからこそ，過去のさまざまな思想や活動との近似性を説明することができているのであって， その逆ではないのである.

\section{[文献]}

渥美俊一, 1967, 『小売業成長の秘密』河出書房.

，2007, 『流通革命の真実——日本流通業のルーツがここにある!』ダイヤモンド社.

崔相鐵, 2004, 「家電流通——家電メーカーと家電商人の対立と協調」石原武政・矢作敏行編『日 本の流通 100 年』有斐閣, 91-132.

近森高明・工藤保則編，2013，『無印都市の社会学—どこにでもある日常空間をフィールドワー クする』法律文化社.

Drucker, P. F, 1962, “The Economy's Dark Continent,” Fortune, 32(4): 265-70. (=1962, 田島義 博訳「経済の暗黒大陸」『中央公論』77(9)：114-23.)

林周二, 1961, 『日本の企業とマーケティング』日本生産性本部.

1962，『流通革命—製品・経路拧よび消費者』中央公論社.

石原武政, 2004, 「中小小売業——過小・過多構造の動態」石原武政・矢作敏行編『日本の流通 100 
年』有斐閣, 263-99.

加島卓, 2014 , 『〈広告制作者〉の歴史社会学——近代日本における個人と組織をめぐる摇らぎ』せ りか書房.

川崎進一, 1972, 『チェーンストアの話』日本経済新聞社.

倉本初夫，1960，「スーパーマーケット概論」倉本初夫・渥美俊一著『日本のスーパーマーケット ——経営の理論』文化社, 14-68.

一， 2005，『倉本長治一一昭和の石田梅岩と言われた男』商業界.

宗像平八郎，1963，「『問屋滅亡論』は本当か」近代経営編集部編『流通革命の焦点』ダイヤモンド

社, 266-74.

長戸毅, 1991, 『流通革新一一日本の源流』同友館.

中内功, 1969, 『わが安売り哲学』日本経済新聞社.

新倉貴仁， 2015，「戦後社会とオートメーション一工業化社会から消費社会への変容の技術的条

件」『マス・コミュニケーション研究』86: 143-60.

——, 2016, 『「能率」の共同体一一近代日本のミドルクラスとナショナリズム』岩波書店.

奥住正道, 1983, 『証言・戦後商業史——流通を変えた 100 人の記録』日本経済新聞社.

坂本二郎，1963，「アメリカ型消費を前提してよいか」近代経営編集部編『流通革命の焦点』ダイ

ヤモンド社, 250-8.

内田隆三, 1987, 『消費社会と㭲力』岩波書店.

若林幹夫編，2013，『モール化する都市と社会一巨大商業施設論』NTT 出版.

矢作敏行，1997，『小売りイノベーションの源泉——経営交流と流通近代化』日本経済新聞社.

（原稿受付 2016.6.12 掲載決定 2017.7.7） 


\title{
The Logic and Ethics of the "Modernization Movement of Merchandising":
}

Focusing on Retail Consultants' Discourse on Discounting during the 1960s in Japan

\author{
HAYASHI, Ryo \\ Graduate School of Interdisciplinary Information Studies, \\ University of Tokyo \\ assyupokira@gmail.com
}

During the 1960s in Japan, with the rapid expansion of chain stores, there was a structural change in the retail industry. In this period, growing retail companies such as Daiei and Seiyu opened stores in various locations. As a result, mass distribution based on "discounting" was established.

Historical research of the retail industry shows that retail consultants, as a professional group, had a significant role in the industry's structural changes. Their activities, which presented the possibilities of a chain store style that relied on advanced American retailing and business administration, had a major impact at that time. In this regard, how did these consultants pick up on novel management approaches that had previously been denied because of Japanese traditions and succeed in spreading them among retailers? Past studies are unable to answer this question.

In this study, we focus on the discourse of retail consultants who were engaged in "the modernization movement of merchandising" at the time. Our process informs the analysis of consumer society research findings and demonstrates the following points. First, we show that when commercial consultants positively highlighted "discounting" in the "Modernization Movement of Merchandising," "discounting" and "dumping" were disentangled from the frameworks of "mass production" and "mass consumption." Second, we explain that claims for "discounting" were closely related to the introduction of business administration. Third, we elucidate that the practice of "discounting" was driving anticipation for the arrival of a "consuming society," so that the norm of contribution to "consumers" was linked to "discounting."

Key words: Consumption, Retail industry, Mass distribution.

(Received Jun. 12, 2016 / Accepted Jul. 7, 2017) 